\title{
MECHANICAL PROPERTIES OF RAMMED EARTH WITH RESPECT TO CLAY MIXTURE COMPOSITION
}

\author{
Tereza Plaček Otcovská*, Barbora Mužíková, Pavel Padevět
}

\author{
Czech Technical University in Prague, Faculty of Civil Engineering, Department of Mechanics, Thákurova \%, \\ 16629 Prague 6, The Czech Republic \\ * corresponding author: tereza.otcovska@fsv.cvut.cz
}

\begin{abstract}
Unfired earth is a traditional building material, but it is less used than other building materials, such as concrete or steel. But the use of unfired earth is experiencing a renaissance. Rammed earth is a type of unfired earth and is usually used for load bearing structures. This paper describes an experimental determination of the tensile bending strength and compressive strength of the rammed earth specimens with known compositions. Mechanical properties are dependent on these compositions (kind of clay, amount of clay, amount of mixture water). Laboratory specimens were produced without inorganic binders or fibrous admixtures. We observed higher tensile bending strengths and lower compressive strengths in specimen mixtures containing more clay. The obtained results were evaluated in a context of a previous research. The results were also compared with results published by another author.
\end{abstract}

KEYwORDS: Rammed earth, clay, montmorillonite, tensile bending strength, compressive strength, water coefficient, earth mixture.

\section{INTRODUCTION}

This paper presents results of a rammed earth research. The rammed earth research in Department of Mechanics at Czech Technical University in Prague is a primarily experimental one and it is focused on the dependence between the composition of the earth mixture and final rammed earth properties. In the first section, the paper describes the principle of the research and, in the second section, results of a specific part of the research are presented.

Rammed earth is an unfired earthen material created by pressing down layers of earthen mixtures into a formwork (Fig. 11). Unfired earth is one of the world's oldest building materials, but, because of new and modern materials, it has been pushed into the background and nearly abandoned in the construction practise. However, there has been a growing interest in unfired earthen material's resulting in more research [1-3].

Rammed earth represents just a small part of the construction industry, but there are companies who specialize in building modern rammed earth structures [46.

Rammed earth is usually used for load bearing structures, therefore, its mechanical properties are important. Rammed earth is usually not as strong as fired bricks, but the strength of a fired brick masonry is influenced by the strength of mortars. Because of this, the strengths of rammed earth and masonry structures could be comparable. But it is necessary to find a composition of earth mixture, which guarantees sufficient mechanical properties of rammed earth for the load-bearing structures [2, 17.

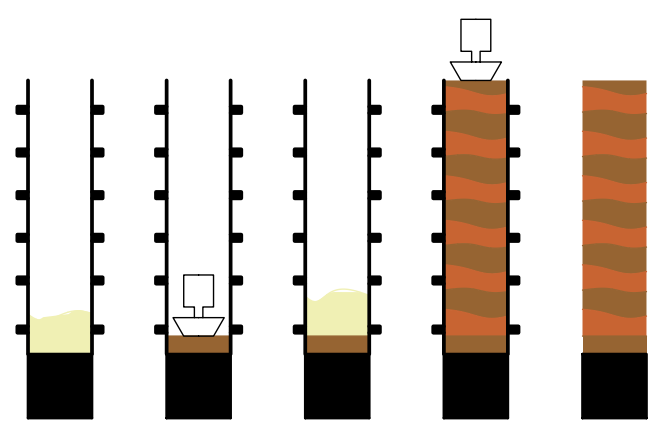

Figure 1. Principle of the rammed earth.

Merely one aspect of our research project (Section 22 is presented in this paper, which describes the experimental determination of the tensile bending strength and compressive strength for rammed earth containing montmorillonite clay. The results obtained were compared to a prior research $8[12$.

The strength of rammed earth blocks are influenced by their composition, dry density and reinforcements or admixtures [2, 13].

Using earth from a construction site is undoubtedly the best path for sustainability in the building industry. However, the composition of earth varies from site to site and it requires a highly experienced and skilled civil engineer to design a load bearing structure, taking into consideration the specific composition he is working with. Interestingly, there has been a technical 
1.

Analysis of dependence between composition of earth mixture and final properties of the rammed earth.

\section{2.}

Determining properties of rammed earth when the composition of an earth mixture is known.

\begin{tabular}{|c|}
\hline Creating source for design \\
of rammed earth.
\end{tabular}

FiguRE 2. Diagram of our research project.

legislation about unfired earth until the first half of the twentieth century [2, 14-16].

There are a number of previous investigations focused on the mechanical properties of rammed earth. At present, norms or methodologies do not exist for the design of unfired constructions in the Czech Republic and in many other countries [2, 14, 15, 17, 18.

A reliable methodology for earth design will be very important for expanding of the unfired earth material industry. Knowledge of the mechanical properties of rammed earth depends on the analysis of the earth mixture's composition. On the basis of such analyses, it would be possible to define the dependence of final rammed earth properties on the composition of their mixtures. In other words, a quality resource for the design of rammed earth structures can only be created when we can determine the final product properties for mixtures containing specific kinds and amounts of clay and specific amount of mixture water. The above described is illustrated in Figure 2, [2, 6].

The strength of a final material is one of the most important properties in the design of load bearing rammed earth structures. This is why this article focuses on tensile bending strength and compressive strength. These properties were investigated using laboratory-made earth mixtures of known compositions (specific clay types, sand and clay ratios, and water coefficient).

The biggest disadvantage of the unfired clay is the insufficient resistance to water. Therefore, many scientific investigations examine unfired clay containing inorganic binders (for example lime or cement), which improve the water resistance [19 21].

Cement and lime increase the water resistance due to chemical reactions. Cement is a hydraulic binder, which hardens due to a hydraulic activity and, after setting, stays solid in water. The setting of lime is caused by carbonation. Calcium carbonate $\left(\mathrm{CaCO}_{3}\right)$ is the product of carbonation and it is poorly soluble in water (solubility in water is approximately $0.01 \mathrm{~g} / \mathrm{L}$ at $\left.25^{\circ} \mathrm{C}\right]^{1}$. The clay minerals that act as a binder in unfired earthen materials acquire their strength only during the drying process and clay minerals lose strength due to the influence of moisture. Creating a water-repellent coating on the surface of unfired earthen material structures provides a good protection against the influence of moisture [2, 6, 22, 25].

Inorganic binders are not necessary for rammed earth constructions. Rammed earth can be sufficiently resistant to moisture. Historic buildings such as the Great Wall of China and historic buildings of lesser importance are sufficiently resistant to weathering. This is why these buildings provide a tangible evidence of the durability of rammed earth structures. Rammed earth is a sufficiently resistant material for the building industry, but only with suitable earth mixtures and correct structure designs. This is why our project was focused on the properties of rammed earth without additives 2, 26-28.

\section{Aim, Materials, and Methods}

The main idea of our entire research is presented in this chapter. The obtained results were compared to a prior research listed on [8, 9].

The analysis of the relationship between the composition of an earth mixture and its final properties is important for creating a resource for rammed earth designs. This is the reason why we used different kinds and amounts of clay and different amounts of mix water for the production of the earth mixture in our laboratory. The kinds of clay together with the amount of mix water and clay, which are investigated, are listed in Table 1

We also conduct an isotropy of the rammed earth specimens with mechanical properties investigated in parallel and perpendicular plane layers. The orientation of the loading force during experimental measurements described in this paper is shown in Figures 10 and 11

For this paper, we measured the tensile bending and compressive strength of rammed earth specimens containing montmorillonite clay and different amount of mixture water (Table 3).

\subsection{Procedure of Production of Earth Mixtures and Test Specimens}

In general, earth mixtures for experiments are created in the laboratory and consist of three components: sand, clay, and mixture water. The sand acted as a filling agent, the clay functioned as a binder, and the water activated the clay's bonding properties and enabled good earth mixture processing.

Firstly, it is necessary to design the compositions of the earth mixtures. A ratio of sand and clay is defined, and the amount of mixing water is defined using the water coefficient $W$. The water coefficient is defined

\footnotetext{
${ }^{1}$ Calcium carbonate is soluble in water that is saturated with carbon dioxide.
} 


\begin{tabular}{ll}
\hline Kinds of clay & $\begin{array}{l}\text { montmorillonite } \\
\text { illite } \\
\text { illite-kaolinite }\end{array}$ \\
\hline $\begin{array}{l}\text { Amount of mix water } \\
\text { (defined by the water }\end{array}$ & $0.295,0.37$, \\
coefficient) & \\
\hline Sand/clay ratio & $70 / 30,75 / 25$ \\
& $80 / 20,85 / 25$ \\
\hline
\end{tabular}

TABLE 1. Variable components for the production of earth mixtures in our laboratory.

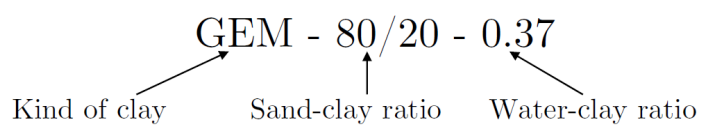

Figure 3. Earth mixture code.

as the water to clay ratio (Equation 1). The proposed earth mixture codes are determined according to the compositions of the earth mixtures (Fig. 3).

$$
W=m_{w} / m_{c}
$$

$W$ - Water coefficient $[-]$.

$m_{w}$ - Weight of water $[\mathrm{g}]$.

$m_{c}$ - Weight of clay [g].

Earth mixtures are manufactured by adding approximately $2 / 3$ of the total quantity of the proposed mixing water to sand, reaching equilibrium moisture (environmental temperature $20^{\circ} \mathrm{C}$, relative humidity $55 \%$ ). Clay is added after that. Earth mixtures are mixed by hand as clay is added. The remaining amount of mixing water (approximately 1/3) is added after incorporating all of the clay and finally mixed using an electric drill and moulded by hand.

Layers of the earth mixture are pressed down using a steel block to steel moulds for created test specimens (Fig. 8). Each test specimen is usually formed by 5 layers. Tensile bending strengths and compressive strengths are tested on the specimens.

This procedure is same for all of the test specimens.

Three kinds of test specimens are created $(20 \times 20 \times 100 \mathrm{~mm}, 40 \times 40 \times 160 \mathrm{~mm}$, and octagon specimens with a $8.3 \mathrm{~mm}$ side and $70 \mathrm{~mm}$ long) (Fig. 4 .

48 kinds of earth mixtures are scheduled for testing (combination of parameters listed in Table 1). Three test specimens are considered to be the minimum number for every experimental test, thus, 288 test specimens are designed only for the tensile bending strength and compressive strength experiments. The test specimen size was selected because of the large number of specimens needed and the difficulty of the production. It is necessary to investigate a wide range of test specimens with different compositions

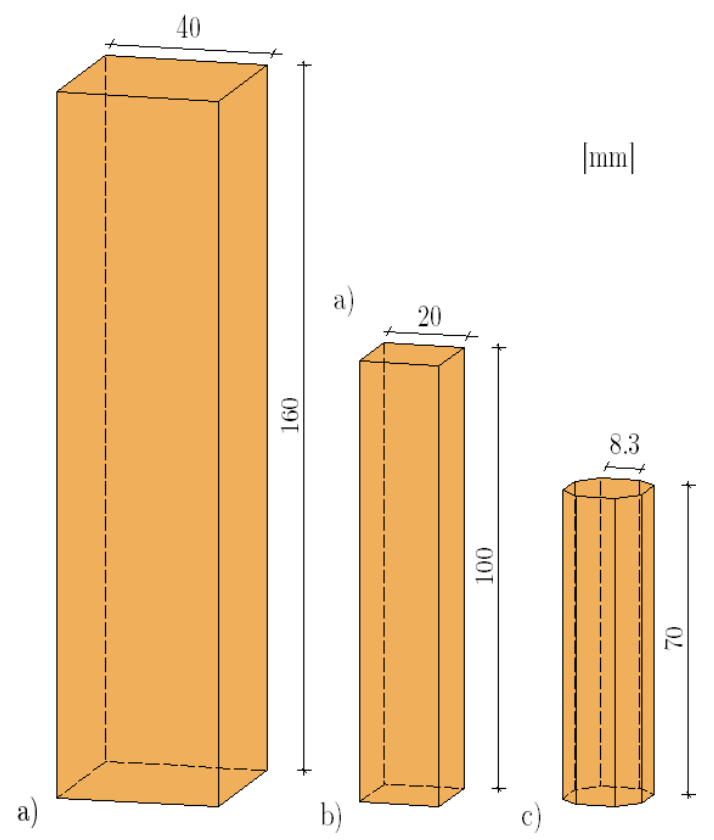

Figure 4. Test specimens size.

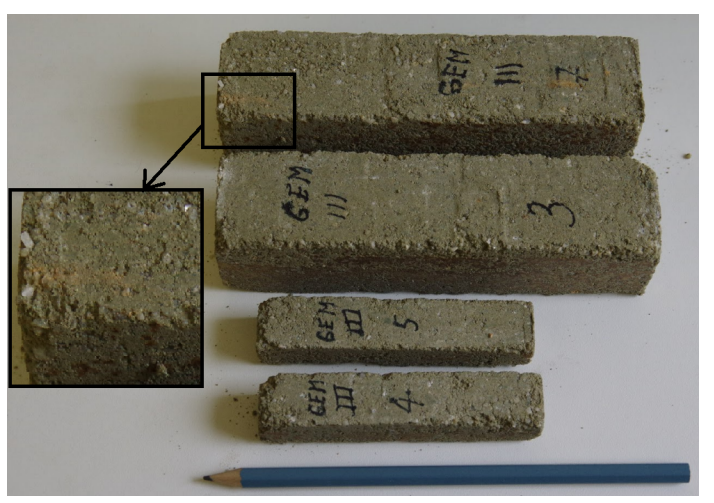

Figure 5. Test specimens $(20 \times 20 \times 100 \mathrm{~mm}$, $40 \times 40 \times 160 \mathrm{~mm})$.

and subsequently verify the obtained results, which will better correspond to real structures.

Rammed earth mixtures usually contain gravel and stones, but our laboratory mixtures did not contain these components. The granularity of the filling agent was chosen with respect to the test specimens' size.

\subsection{Test Materials, Test Specimens And Experimental MeAsurement}

The earth mixtures described in this paper were composed of siliceous sand, montmorillonite clay, and water. Montmorillonite clay is one of investigated clays of the entire research. The sand and clay ratio was chosen based on a previous experience with a processability of earth mixtures. A grain curve for the sand is provided in the Fig. 7. The specific composition of the used clay is listed in Table 2 The investigation of rammed earth of this composition is a part of the search for the optimal composition of earth mixture. 


\begin{tabular}{lccccccccc}
\hline Mark & $\begin{array}{c}\text { Particle size } \\
\text { Clay }\end{array}$ & $\begin{array}{c}\mathrm{SiO}_{2} \\
\mathrm{Al}_{2} \mathrm{O}_{3}\end{array}$ & $\begin{array}{c}\mathrm{Fe}_{2} \mathrm{O}_{3} \\
{[\%]}\end{array}$ & $\begin{array}{c}\mathrm{TiO}_{2} \\
{[\%]}\end{array}$ & $\begin{array}{c}\mathrm{CaO} \\
{[\%]}\end{array}$ & $\begin{array}{c}\mathrm{MgO} \\
{[\%]}\end{array}$ & $\begin{array}{c}\mathrm{Na}_{2} \mathrm{O} \\
{[\%]}\end{array}$ & $\begin{array}{c}\mathrm{K}_{2} \mathrm{O} \\
{[\%]}\end{array}$ & {$[\%]$} \\
\hline Montmorillonite (GEM) & 0.31 & 50.51 & 31.2 & 3.37 & 0.86 & 0.4 & 0.42 & 0.08 & 1.62 \\
Illite (AGL) & 0.4 & 56.57 & 18.4 & 9.72 & 1.16 & 1.12 & 2.54 & 0.18 & 2.91 \\
Illite-kaolinite (KR) & 8.26 & 59.31 & 24.71 & 3.37 & 1.09 & 0.19 & 0.4 & 0.3 & 2.82 \\
\hline
\end{tabular}

TABLE 2. Composition of used clay.

\begin{tabular}{|c|c|c|c|c|c|c|}
\hline \multirow[t]{2}{*}{ Set } & \multirow[t]{2}{*}{ Clay } & \multirow{2}{*}{$\begin{array}{c}\text { Sand/clay } \\
\text { Ratio }\end{array}$} & \multirow{2}{*}{$\begin{array}{l}\text { Water/clay } \\
\text { Ratio [-] }\end{array}$} & \multicolumn{3}{|c|}{ Number of test specimens $[\mathrm{ks}]$} \\
\hline & & & & $\begin{array}{l}40 \times 40 \times 160 \mathrm{~mm} \\
\quad(\text { Fig. } 4 \text { a }))\end{array}$ & $\begin{array}{l}20 \times 20 \times 100 \mathrm{~mm} \\
\quad(\text { Fig. } 4 \text { b) })\end{array}$ & $\begin{array}{c}\text { octagon base } \\
\text { á } 8.3 \times 70 \mathrm{~mm} \\
\quad(\text { Fig. } 4 \text { c }))\end{array}$ \\
\hline GEMI & montmorillinite & $80 / 20$ & 0.37 & 6 & 4 & - \\
\hline GEMII & montmorillinite & $75 / 25$ & 0.37 & 6 & 6 & - \\
\hline GEMIII & montmorillinite & $75 / 25$ & 0.295 & 4 & - & 4 \\
\hline
\end{tabular}

TABlE 3. Composition of clay mixture batches and number of test specimens.

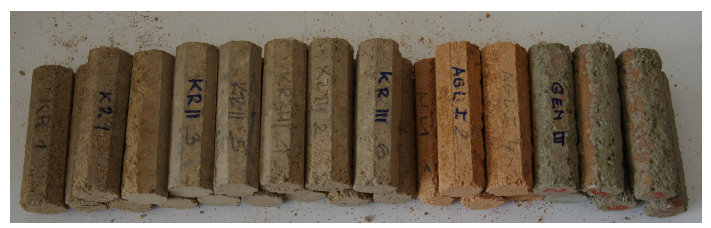

Figure 6. Octagon test specimens.

Three earth mixtures were manufactured (GEMI, GEMII, GEMIII). The earth mixtures varied in terms of the amounts of montmorillonite clay and mixing water. Test specimens were manufactured from these earth mixtures (Fig. 5 and Fig. 6).

The specific compositions and numbers of all earth mixture sets are shown in Table 3 The test specimens were pressed manually.

The $40 \times 40 \times 160 \mathrm{~mm}$ specimens were pressed using a steel block $(20 \times 50 \times 109 \mathrm{~mm}, 853.5 \mathrm{~g})$ (Fig. 8). The smaller test specimens were pressed using a steel block $12 \times 40 \times 65 \mathrm{~mm}$ and $244 \mathrm{~g}$.

The specimens were taken out of moulds immediately after the manufacturing. Tensile bending strengths and compressive strengths were tested after the equilibrium moisture was reached in the laboratory environment $\left(20^{\circ} \mathrm{C}\right.$, relative humidity $\left.55 \%\right)$, minimally 40 days after the manufacturing. The exact sizes of all specimens were measured using a digital calliper.

Tensile bending strength was tested on 6 GEMI specimens, 6 GEMII specimens and 4 GEMIII specimens. Tensile bending strength test specimens were $40 \times 40 \times 160 \mathrm{~mm}$ each. Tensile bending strength was determined using a three-point bending test (Fig. 9). The distance between supports for the three-point bending test was $140 \mathrm{~mm}$. The orientation of the loading force was parallel to the layers (Fig. 10.
Compressive strength was tested on 4 GEMI specimens, 6 GEMII specimens, and 4 GEMIII specimens. The compressive strength of the GEMI and GEMII sets was tested on block-shaped specimens $(20 \times 20 \times 100 \mathrm{~mm})$. Compressive strength for the GEMIII set was tested using specimens with an octagon base $(8.3 \times 70 \mathrm{~mm})$. The orientation of the loading force during the compressive strength tests was parallel to the plane layers (Fig. 11).

\subsubsection{MATERIAL TESTED IN PREVIOUs RESEARCH}

The results published in this paper are compared with the results of our previous research published in [8] and 9 . The results of this previous research were obtained by the same experimental measurement as described in the chapter 2.2. The earth mixture of previous research with a set code $\mathrm{S}$ containing the same amount of sand and clay ratios and the same value of the water coefficients like the GEM mixtures. The only difference between the GEM and S mixtures was the type of the clay. Illitic-kaolinitic clay was used for the $\mathrm{S}$ mixtures.

\section{Results and Discussion}

There were minimally 4 test specimens for every tensile bending strength and compressive strength tests. Averages and standard deviations were calculated from the measured values. Since clay is a binder in earth mixtures, it was assumed that the strength of the rammed earth would increase as the amount of clay increased.

\subsection{Tensile Bending Strength}

The tensile bending strength measured for the GEMI specimens is shown in Table 4 The average tensile 


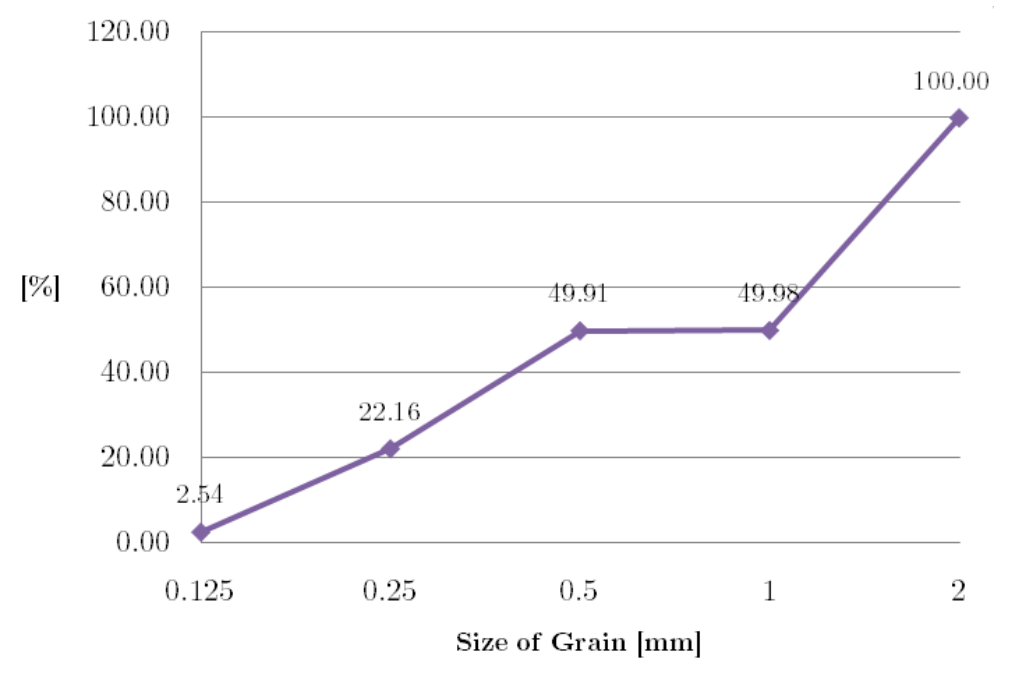

FiguRE 7. Grain curve for the used sand.

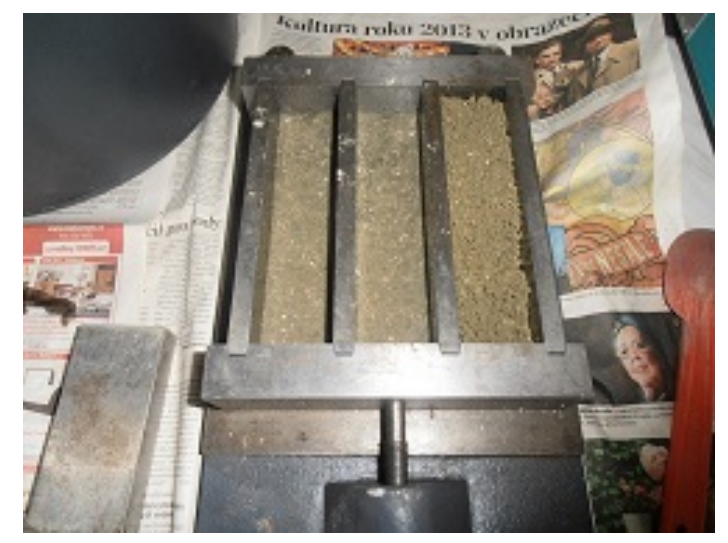

Figure 8. Production of the test specimens.

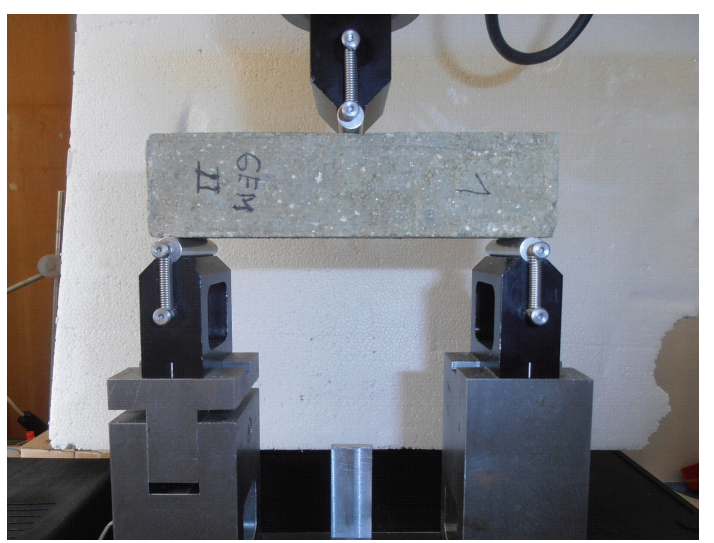

Figure 9. Three-point bend test.

bending strength was $0.38 \mathrm{MPa}$ and the standard deviation was $0.04 \mathrm{MPa}$ (approximately $10.5 \%$ of the calculated average tensile bending strength).

The measured tensile bending strength for the GEMII specimens is shown in Table 5. The average tensile bending strength was $0.39 \mathrm{MPa}$ and the standard deviation was $0.04 \mathrm{MPa}$ (approximately 10.2\% of the calculated average tensile bending strength).
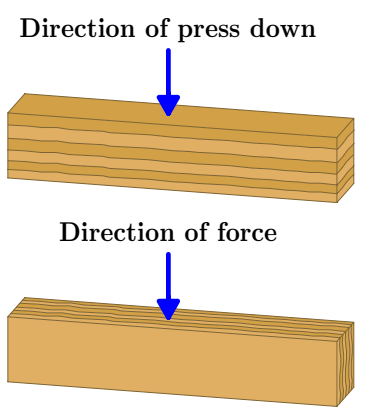

FiguRE 10. Direction of the pressing during the production of the test specimens and the direction of the force for the three-point bend test.

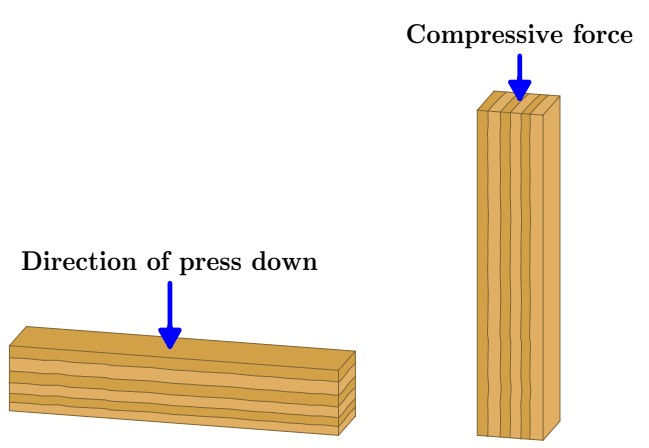

FiguRE 11. Direction of the pressing during the production of the test specimens and the direction of the compressive force.

The measured tensile bending strength for the GEM III set specimens is shown in Table 6. The average tensile bending strength was $0.35 \mathrm{MPa}$ and the standard deviation was $0.03 \mathrm{MPa}$ (approximately $8.6 \%$ of the calculated average tensile bending strength). 


\begin{tabular}{lcccc}
\hline Test specimens & Size $[\mathrm{mm}]$ & Sand/clay ratio & Water/clay ratio & Tensile bending strength $[\mathrm{MPa}]$ \\
\hline GEMI - 1 & $40 / 40 / 160$ & $80 / 20$ & 0.37 & 0.30 \\
GEMI - 2 & $40 / 40 / 160$ & $80 / 20$ & 0.37 & 0.39 \\
GEMI - 3 & $40 / 40 / 160$ & $80 / 20$ & 0.37 & 0.34 \\
GEMI - 4 & $40 / 40 / 160$ & $80 / 20$ & 0.37 & 0.38 \\
GEMI - 5 & $40 / 40 / 160$ & $80 / 20$ & 0.37 & 0.42 \\
GEMI - 6 & $40 / 40 / 160$ & $80 / 20$ & 0.37 & 0.42 \\
\hline \multicolumn{5}{c}{ Average tensile bending strength } \\
Standard deviation & $\mathbf{0 . 3 8}$ \\
\hline
\end{tabular}

TABLE 4 . The tensile bending strength of the GEMI set - the test specimens $40 \times 40 \times 160 \mathrm{~mm}$.

\begin{tabular}{lcccc}
\hline Test specimens & Size $[\mathrm{mm}]$ & Sand/clay ratio & Water/clay ratio & Tensile bending strength [MPa] \\
\hline GEMII - 1 & $40 / 40 / 160$ & $75 / 25$ & 0.37 & 0.37 \\
GEMII - 2 & $40 / 40 / 160$ & $75 / 25$ & 0.37 & 0.39 \\
GEMII - 3 & $40 / 40 / 160$ & $75 / 25$ & 0.37 & 0.45 \\
GEMII - 4 & $40 / 40 / 160$ & $75 / 25$ & 0.37 & 0.33 \\
GEMII - 5 & $40 / 40 / 160$ & $75 / 25$ & 0.37 & 0.39 \\
GEMII - 6 & $40 / 40 / 160$ & $75 / 25$ & 0.37 & 0.43 \\
\hline \multicolumn{5}{c}{ Average tensile bending strength } \\
Standard deviation & $\mathbf{0 . 3 9}$ \\
\hline
\end{tabular}

TABLE 5. The tensile bending strength of the GEMII set - the test specimens $40 \times 40 \times 160 \mathrm{~mm}$.

By comparing GEMI and GEMII set results manufactured with the same water coefficients $W=m_{w} / m_{c}$ and differentianting just in the amount of montmorillonite clay, we find that the GEMII set had the highest tensile bending strength (Fig. 12). The average tensile bending strength for the GEMI set (sand/clay ration 80/20) was $0.38 \mathrm{MPa}$, for the GEMII set (sand/clay ratio $75 / 25$ ), it was $0.39 \mathrm{MPa}$. The GEMII set contained 5\% more clay than the GEMI set. We can, therefore, assume that the tensile bending strength of specimens with the percent amount of clay ${ }^{2}$ on an interval $<20,25\rangle$ rose as the amount of montmorillonitic clay in specimens increased. We can assume, based on the previous research, that the described dependence between the clay amount in the mixture and the resulting tensile bending strength will be valid even on a wider interval 8 .

The GEMII and GEMIII sets contained the same amount of clay (sand/clay ratio $75 / 25$ ) and different water coefficients. The GEMII set with a higher water coefficient $(\mathrm{W}=0.37)$ attained a tensile bending strength of 0.39 MPa. The GEMIII set with a lower water coefficient $(\mathrm{W}=0.295)$ attained a value of 0.35 MPa (Fig. 13). It can be assumed that the high water coefficient in the interval of $\langle 0.295,0.37\rangle$, while using

\footnotetext{
${ }^{2}$ Percentage amount of clay in the dry mix i.e., clay mixture without water.
}

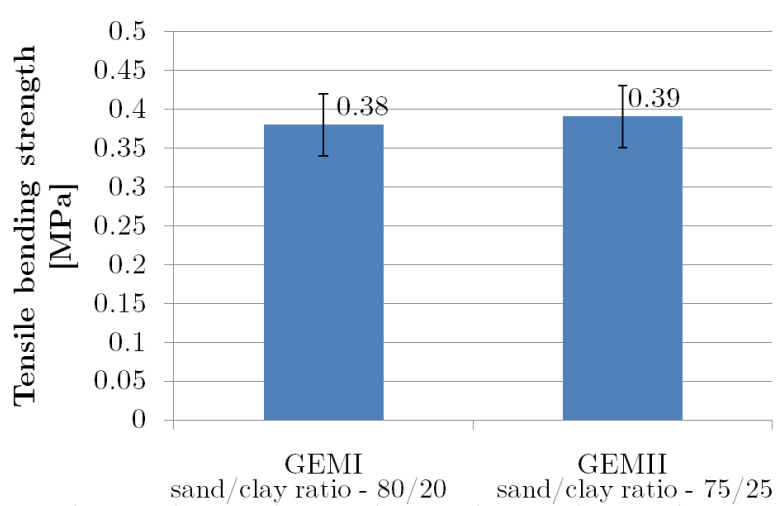

FiguRE 12. Results of average values for tensile bending strength, dependent on the amount of clay in the mixtures.

the montmoriloonitic clay, had a positive influence on the resulting tensile bending strength.

It was necessary to place the results into the context of other experimental measurements. In [8], we conducted the same experiment for mixtures with set codes SI, SII, and SIV. The only difference between the GEM and S mixtures is in the type of clay. Illitic-kaolinitic clay was used for the S mixtures and montmorillonitic clay for the GEM mixtures.

The values attained for the tensile bending strength $\mathrm{S}$ sets illustrate the same trend of a dependence of 


\begin{tabular}{|c|c|c|c|c|}
\hline Test specimens & Size $[\mathrm{mm}]$ & Sand/clay ratio & Water/clay ratio & Tensile bending strength $[\mathrm{MPa}]$ \\
\hline GEMIII - 1 & $40 / 40 / 160$ & $75 / 25$ & 0.295 & 0.37 \\
\hline GEMIII - 2 & $40 / 40 / 160$ & $75 / 25$ & 0.295 & 0.35 \\
\hline GEMIII - 3 & $40 / 40 / 160$ & $75 / 25$ & 0.295 & 0.32 \\
\hline GEMIII - 4 & $40 / 40 / 160$ & $75 / 25$ & 0.295 & 0.39 \\
\hline \multirow{2}{*}{\multicolumn{4}{|c|}{$\begin{array}{c}\text { Average tensile bending strength } \\
\text { Standard deviation }\end{array}$}} & 0.35 \\
\hline & & & & 0.03 \\
\hline
\end{tabular}

TABLE 6. The tensile bending strength of the GEMIII set - the test specimens $40 \times 40 \times 160 \mathrm{~mm}$.

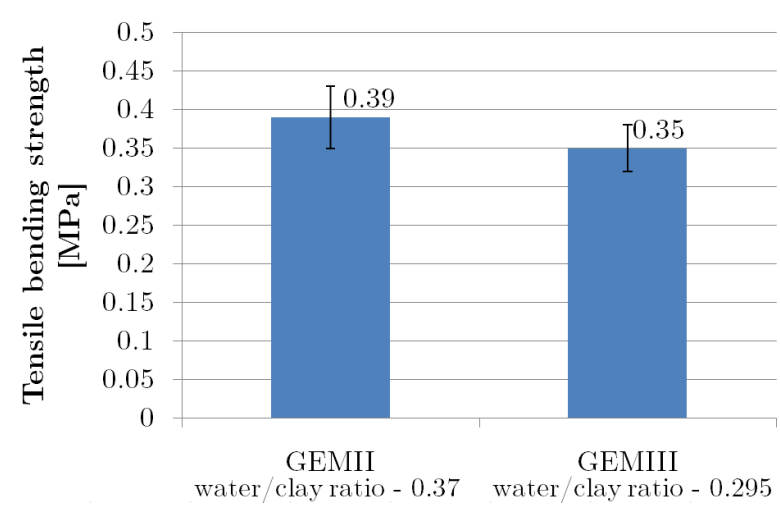

FiguRE 13. Results of average values for tensile bending strength, dependent on the amount of mix water in the mixtures.

strength on the amounts of clay used. The tensile bending strength increased with an increasing clay amount for both S and GEM sets. In contrast, the dependence of strength on the amounts of mixture water seems to have been inverse for the S and GEM sets. For the GEM sets, tensile bending strength increased with a greater amount of mixture water, but the $\mathrm{S}$ sets exhibited an opposite trend 8 .

\subsection{Compressive Strength}

The values attained for GEMI set's compressive strength are listed in Table 7 The average compressive strength was $1.27 \mathrm{MPa}$ and the standard deviation was $0.16 \mathrm{MPa}$ (approximately $12.6 \%$ of the average strength).

The values attained for compressive strength are listed in Table 8 The average compressive strength was $1.21 \mathrm{MPa}$ and the standard deviation was 0.17 $\mathrm{MPa}$ (approximately 14\% of the average strength).

The compressive strength for the GEMIII set was measured on four specimens. Compressive strength for specimen Nr. 2 was distinctly higher than the compressive strength of other specimens (approximately by $50 \%$ ). The compressive strength for specimen $\mathrm{Nr}$. 2 was, for this reason, excluded from further statistical processing. The average compressive strength was $1.42 \mathrm{MPa}$ and the standard deviation was $0.16 \mathrm{MPa}$ (approx. $11.3 \%$ of the average strength) (Table 9 ).

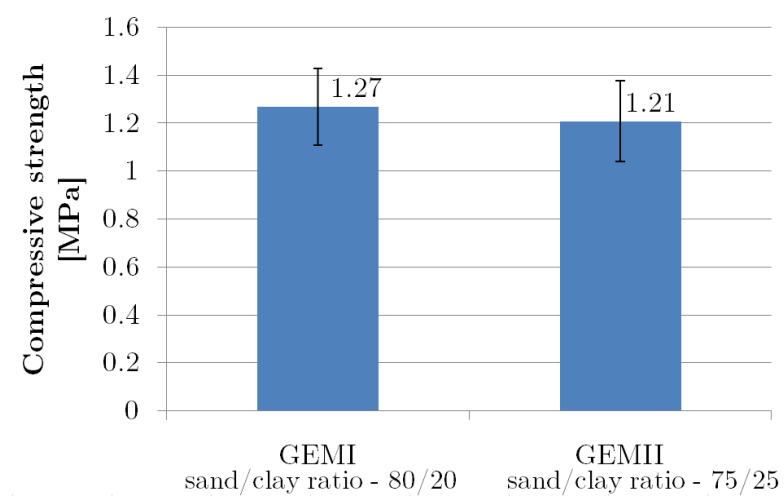

FiguRE 14. Results of average values for compressive strength, dependent on the amount of clay in the mixtures.

Regarding the dependence of the compressive strength on the amount of clay used, our results indicate that compressive strength decreases with an increasing amount of clay for the percentage amount of the montmorillonite clay ${ }^{1}<20,25>$ interval (Fig. 14). The GEMI set (sand/clay ratio 80/20) contained 5\% less clay than the GEMII set (sand/clay ratio $75 / 25$ ). The compressive strength of the GEMI set attained a value of $1.27 \mathrm{MPa}$ while the GEMII compressive strength was only 1.21 MPa. A positive dependence was not confirmed in this case.

The GEMII and GEMIII sets contained the same amount of clay (sand/clay ratio $75 / 25$ ) but a different amount of mixture water. The GEMII water coefficient was 0.37 and the GEMIII water coefficient was 0.295. The average compressive strength for the GEMII set was $1.21 \mathrm{MPa}$ and $1.42 \mathrm{MPa}$ for the GEMIII set. Based on these results, we can state that the higher water coefficient interval $<0.295,0.37>$ had a negative impact on the final compressive strength with montmorillonite clay specimens (Fig. 15).

Regarding the tensile bending tests, we tested compressive strengths in 9] for the SI, SII, and SIV sets. The only difference between the GEM and S mixtures was in the type of clay (illite-kaolinite clay for $\mathrm{S}$ mixtures). The values acquired for the compressive strength for the GEM sets had the same dependence of compressive strength on the amount of clay as for the $\mathrm{S}$ sets (interval of the percentage amount of mont- 


\begin{tabular}{lcccc}
\hline Test specimens & Size $[\mathrm{mm}]$ & Sand/clay ratio & Water/clay ratio & Compressive strength [MPa] \\
\hline GEMI - 1 & $20 / 20 / 100$ & $80 / 20$ & 0.37 & 1.34 \\
GEMI - 2 & $20 / 20 / 100$ & $80 / 20$ & 0.37 & 1.01 \\
GEMI - 3 & $20 / 20 / 100$ & $80 / 20$ & 0.37 & 1.33 \\
GEMI - 4 & $20 / 20 / 100$ & $80 / 20$ & 0.37 & 1.42 \\
\hline \multicolumn{5}{c}{ Average compressive strength } \\
Standard deviation & $\mathbf{1 . 2 7}$ \\
\hline
\end{tabular}

TABLE 7 . The compressive strength of the set GEMI - the test specimens $20 \times 20 \times 100 \mathrm{~mm}$.

\begin{tabular}{lcccc}
\hline Test specimens & Size $[\mathrm{mm}]$ & Sand/clay ratio & Water/clay ratio & Compressive strength [MPa] \\
\hline GEMII - 1 & $20 / 20 / 100$ & $75 / 25$ & 0.37 & 1.07 \\
GEMII - 2 & $20 / 20 / 100$ & $75 / 25$ & 0.37 & 0.98 \\
GEMII - 3 & $20 / 20 / 100$ & $75 / 25$ & 0.37 & 1.10 \\
GEMII - 4 & $20 / 20 / 100$ & $75 / 25$ & 0.37 & 1.43 \\
GEMII - 5 & $20 / 20 / 100$ & $75 / 25$ & 0.37 & 1.26 \\
GEMII - 6 & $20 / 20 / 100$ & $75 / 25$ & 0.37 & 1.42 \\
\hline \multicolumn{5}{c}{ Average compressive strength } \\
Standard deviation & $\mathbf{1 . 2 1}$ \\
\hline
\end{tabular}

TABLE 8. The compressive strength of the set GEMII - the test specimens $20 \times 20 \times 100 \mathrm{~mm}$.

\begin{tabular}{|c|c|c|c|c|}
\hline Test specimens & Size $[\mathrm{mm}]$ & Sand/clay ratio & Water/clay ratio & Compressive strength $[\mathrm{MPa}]$ \\
\hline GEMIII - 1 & $\begin{array}{c}\text { length } 70 \mathrm{~mm} \\
\text { side of octagon } 8.3 \mathrm{~mm}\end{array}$ & $75 / 25$ & 0.295 & 1.43 \\
\hline GEMIII - 2 & $\begin{array}{l}\text { length } 70 \mathrm{~mm} \\
\text { side of octagon } 8.3 \mathrm{~mm}\end{array}$ & $75 / 25$ & 0.295 & 2.41 \\
\hline GEMIII - 3 & $\begin{array}{l}\text { length } 70 \mathrm{~mm} \\
\text { side of octagon } 8.3 \mathrm{~mm}\end{array}$ & $75 / 25$ & 0.295 & 1.22 \\
\hline GEMIII - 4 & $\begin{array}{l}\text { length } 70 \mathrm{~mm} \\
\text { side of octagon } 8.3 \mathrm{~mm}\end{array}$ & $75 / 25$ & 0.295 & 1.61 \\
\hline \multicolumn{4}{|c|}{$\begin{array}{c}\text { Average compressive strength } \\
\text { (the compressive strength of sample } 2 \text { is excluded) }\end{array}$} & 1.42 \\
\hline \multicolumn{4}{|c|}{$\begin{array}{c}\text { Standard deviation } \\
\text { (the compressive strength of sample } 2 \text { is excluded) }\end{array}$} & 0.16 \\
\hline
\end{tabular}

TABLE 9. The compressive strength of the set GEMIII - the test specimens with an octagonal plinth. 


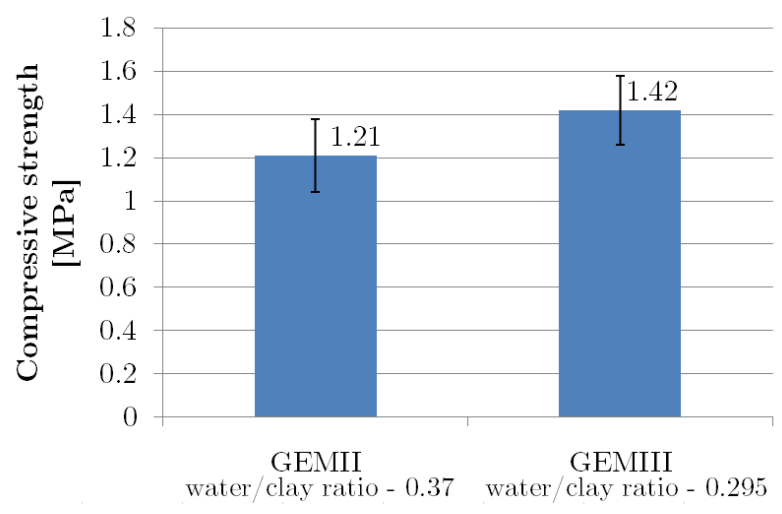

FiguRE 15. Average values of compressive strength, dependent on the amount of mix water in the mixtures.

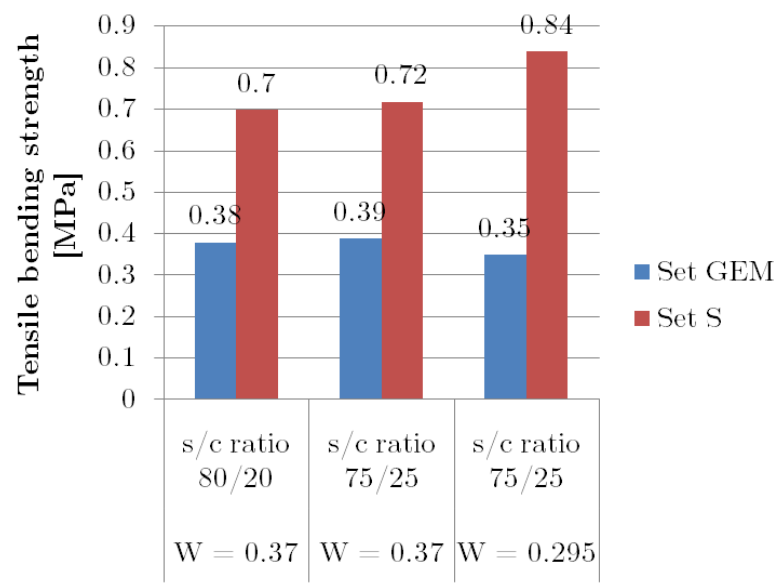

FiguRE 16. Average values for tensile bending strength, GEM and S sets.

morillonite clay $<20,25>$ ). Compressive strength decreased with a lower amount of clay [9].

The dependence of compressive strength on the amount of mixture water was opposite when compared with the S sets. The compressive strength of the GEM sets decreased with an increasing amount of mixture water, while the compressive strength of the $\mathrm{S}$ sets increased [9].

\subsection{Comparison of Results with Previous Research}

Our experimental measurements showed that the interval of tensile bending strength for rammed earth with montmorillonite clay ranged from $0.35 \mathrm{MPa}$ to $0.39 \mathrm{MPa}$. The interval of compressive strength of the same materials ranged from $1.21 \mathrm{MPa}$ to 1.42 $\mathrm{MPa}$ (amounts of clay from $20 \%$ to $25 \%$ and water coefficients $W \in<0.295,0.37>$ ). The results are summarized in Table 10 and in Figures 16 and 17

Experimental measurements proved that tensile bending strength for the specimens with montmorillonite clay as a bonding agent was significantly lower than compressive strength. The computed dependences between tensile bending strength and com-

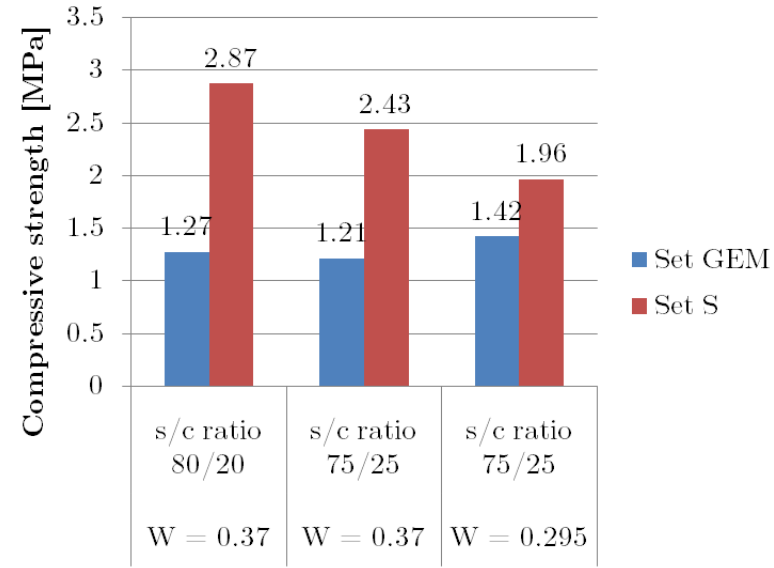

Figure 17. Average values for compressive strength, GEM and S sets.

pressive strength for the specimens tested is shown in Equation 2

$$
R_{G E M, c}=R_{G E M, t} \cdot(4.5 \div 5)
$$

$R_{G E M, c}$ - Compressive strength of the GEM sets $[\mathrm{MPa}]$.

$R_{G E M, t}$ - Tensile bending strength of the GEM sets $[\mathrm{MPa}]$.

In comparison to experiments carried out with the $\mathrm{S}$ sets in the past ( $[\underline{8}$ and $[9]$ ), the difference between the tensile bending strength and the compressive strength was higher. The dependences between the tensile bending strength and the compressive strength for the $\mathrm{S}$ sets is described by Equation 3

$$
R_{S, c}=R_{S, t} \cdot(3.3 \div 4.1)
$$

$R_{S, c}$ - Compressive strength of S set [MPa].

$R_{S, t}$ - Tensile bending strength of S set [MPa].

It can be stated that the results acquired confirm the trend observed during the testing of the $\mathrm{S}$ set mechanical properties. It seems that when the percentage amount of clay is in the interval $\langle 20,25\rangle$, the tensile bending strength rises as the amount of clay increases while compressive strength drops (Fig. 16. Fig. 17).

If additional results for experimental measurements do not disprove the trend we observed, it is necessary to state the clay amount interval in order to acquire complex characteristics for unfired rammed earth materials for which the described dependences of material strength on the amount of clay used is valid.

It was found that the tensile bending strength of the test specimens, which contain the montmorillonite clay and with a mixture water amount in the interval of $W \in<0.295,0.37>$, increases with an increasing water coefficient, while the compressive strength 


\begin{tabular}{lcccc} 
Test specimens & Sand/clay ratio & Water/clay ratio & $\begin{array}{c}\text { Tensile bending strength } \\
{[\mathrm{MPa}]}\end{array}$ & $\begin{array}{c}\text { Compressive strength } \\
{[\mathrm{MPa}]}\end{array}$ \\
\hline GEMI & $80 / 20$ & 0.37 & $0.38( \pm 0.04)$ & $1.27( \pm 0.16)$ \\
GEMII & $75 / 25$ & 0.37 & $0.39( \pm 0.04)$ & $1.21( \pm 0.17)$ \\
GEMIII & $75 / 25$ & 0.295 & $0.35( \pm 0.03)$ & $1.42( \pm 0.16)$ \\
\hline
\end{tabular}

TABLE 10. Summary of experimental results.

decreases (Fig. 13. Fig. 15). Again, it would be desirable to widen the water coefficient interval $W$ and state the maximum water coefficient range for which this dependence is valid.

The results of experimental measurements of the GEM clay mixtures show that, for an interval of water coefficient $W \in<0.295,0.37>$, an inverse dependency on both resultant tensile bending strength and compressive strength was observed in comparison to the $\mathrm{S}$ sets. These results were probably caused by the different kinds of clay used in these mixture (Fig. 16. Fig. 17] [8, 9].

\subsection{Comparison of Results with RESEARCH OF ANOTHER AUTHOR}

The tensile bending strength $(0.35 \div 0.39 \mathrm{MPa})$ and the compressive strength $(1.21 \div 1.42 \mathrm{MPa})$ were lower than many results obtained by other researchers 8,10 12, 29, so we compared our results with a doctoral dissertation 10 .

The reason for this choice was that the dissertation used similar experimental measures, includes the same testing methods and sizes of test specimens $(40 \times 40 \times 160 \mathrm{~mm})$. Earth for the experiments described in [10 was acquired from Claygar s.r.o. and contained kaolinite clay, with montmorillonite clay in minor quantities. Earth mixtures in [10] were labeled C_S40/W10, C_S30/W10, C_S30/W11, C_S30/W11, C_S30/W12, C_S30/W14.

Figures 18 and 19 show results of tensile bending and compressive strength compared to the results in [10]. There is a significant difference between results, most likely because a different amount and kinds of clay as well as a different amount of mixing water were used. This illustrates the importance of the composition of earth mixtures.

The results in 10 show that tensile bending strength increases with an increasing amount of mixing water (Fig. 18, blue part of the graph). These results correspond to our results.

\section{Conclusions}

Further research into the composition of rammed earth mixtures is necessary for a future development of the earthen materials industry. The results presented in this paper represent just a part of a more complex research project focused on a closer exhumation of rammed earth properties and composition.

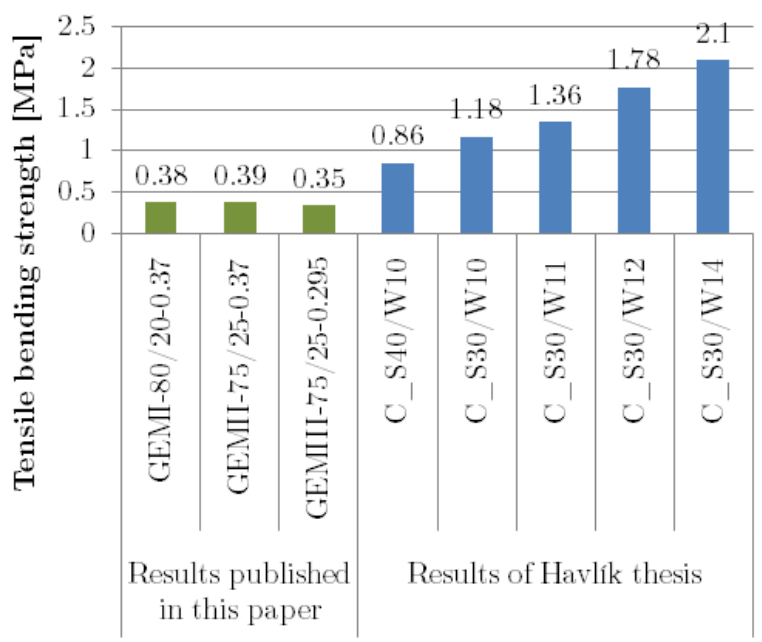

Figure 18. Comparision of average values of tensile bending strength.

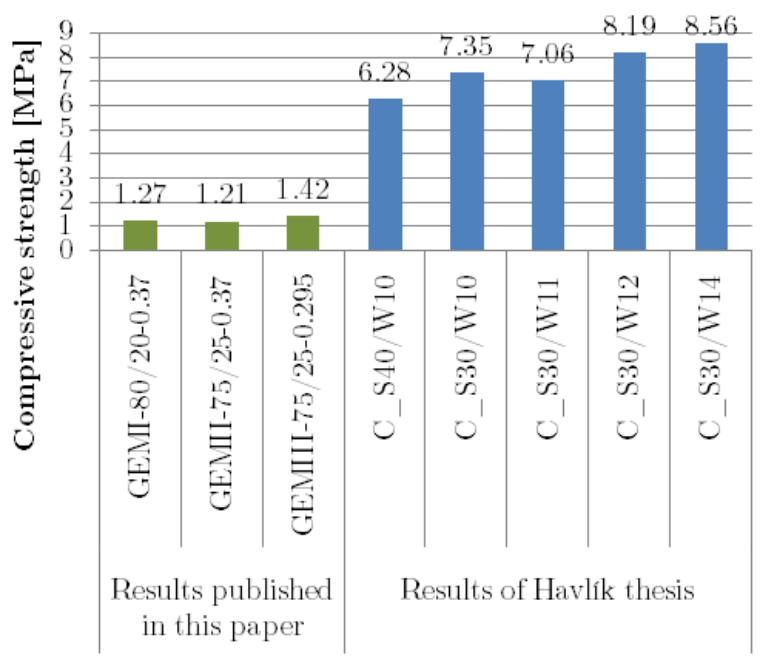

FiguRE 19. Comparison of average values of compressive strength.

The results, in the context of the previous research [8, 9], show that tensile bending strength increases with an increasing amount of clay. Compressive strength, unlike tensile bending strength, decreases with an increasing amount of clay. The dependence between strength and the amount of mixing water we observed has not been proven in the context of previous research ${ }^{3}$

\footnotetext{
${ }^{3}$ Applies to the water coefficient and clay amount interval.
} 
In our research project, tensile bending strength $0.35 \div 0.39 \mathrm{MPa}$ and compressive strength $1.21 \div 1.42$ $\mathrm{MPa}$ were obtained. This values are smaller than in many other investigations. The comparison of our results with [10] shows that the composition of earth mixtures should be a starting point of future investigations.

Our future research will be supplemented by investigations of additional rammed earth specimens containing other kinds of clay and water coefficient intervals.

\section{LIST OF SYMBOLS}

$W$ Water coefficient $[-]$

$m_{w}$ Weight of water $[\mathrm{g}]$

$m_{c}$ Weight of clay [g]

$m_{s}$ Weight of sand [g]

$R_{G E M, c}$ Compressive strength of GEM set [MPa]

$R_{G E M, t}$ Tensile bending strength of GEM set [MPa]

$R_{S, c}$ Compressive strength of $\mathrm{S}$ set [MPa]

$R_{S, t}$ Tensile bending strength of S set [MPa]

\section{ACKNOWLEDGEMENTS}

The financial support of this experiment by the Czech Science Foundation (GAČR project NO. 18-10884S) and Faculty of Civil Engineering, Czech Technical University in Prague (SGS project No. SGS16/201/OHK1/3T/11) is gratefully acknowledged.

We would like to express our thanks to LB MINERALS, s.r.o. company for a free supply of material necessary for the experimental measurement. Acknowledgements also include HELUZ cihlářský průmysl v.o.s. for providing us with statistical data and information. And we would also like to express thanks to Filip Havlík for providing us with results from his research for the comparison.

\section{REFERENCES}

[1] P. Jaquin, C. Augarde. Earth building: History, science and conservation. Report, Bracknell: IHS BRE Press, 2012.

[2] G. Minke. Building With Earth. Ökobuch Verlag, Staufen, 2006.

[3] CRAterre: Accueil. http://craterre.org/, 2018. Accessed: 22 February 2018.

[4] SIREWALL USA Stabilized insulated rammed earth. https://sirewall.com/sirewall-system/, 2018. Accessed: 22 February 2018.

[5] Rammed earth houses | rammed earth walls | the home of Olnee Australia. http://olneerammedearth.com.au/, 2018. Accessed: 22 February 2018.

[6] P. Walker. Rammed Earth: Design and Construction Guidelines, vol. 2010. IHS BRE Press, Watford, 2010.

[7] ČSN EN 1996-1-1 +A1 (731101) - Eurokód 6: Navrhování zděných konstrukcí - Část 1-1: Obecná pravidla pro vyztužené a nevyztužené zděné konstrukce. Standard, American Society for Testing and Materials, 2013.
[8] T. Otcovská, P. Padevět. Dependence of Tensile Bending Strength of Rammed Earth on Used Clay Composition and Amount of Mixture Water. In Modern Methods of Experimental and Computational Investigation in Area of Construction II, pp. 48-53. Trans Tech Publications Ltd, Prague, 2016.

[9] T. Otcovská, P. Padevět. Dependence of Compressive Strength of Rammed Earth on Used Clay Composition. Západočeská universita, Fakulta aplikovaných věd, Srní, 2016.

[10] F. Havlík. Development and Experimental Verification of Mechanical-physical Properties of Pre-formed Rammed Earth Wall Panel, 2017.

[11] Q.-B. Bui, J.-C. Morel, S. Hans, N. Meunier. Compression behaviour of non-industrial materials in civil engineering by three scale experiments: The case of rammed earth. Materials and Structures 42(8):1101-1116, 2009. DOI:10.1617/s11527-008-9446-y.

[12] F. Champiré, A. Fabbri, J.-C. Morel, et al. Impact of relative humidity on the mechanical behavior of compacted earth as a building material. Construction and Building Materials 110:70-78, 2016. DOI:10.1016/j.conbuildmat.2016.01.027.

[13] A. Perrot, D. Rangeard, F. Menasria, S. Guihéneuf. Strategies for optimizing the mechanical strengths of raw earth-based mortars. Construction and Building Materials 167:496-504, 2018. DOI:10.1016/j.conbuildmat.2018.02.055.

[14] Agenda 21 - United Nations Environment Programme (UNEP). http://www . unep.org/Documents . Multilingual/Default.asp?documentid=52. Accessed: 14 February 2017.

[15] Institute for Environment and Sustainability (2010) International Reference Life Cycle Data System (ILCD) Handbook. Publications Office of the European Union, Luxembourg, 2012.

[16] ČSN 1168-1939 - Podmínky pro zednické a přidružené práce pozemních staveb. Standard, 1951.

[17] Q. B. Bui, J. C. Morel, V. H. Tran, et al. How to Use In-situ Soils as Building Materials. Procedia Engineering 145:1119-1126, 2016. DOI:10.1016/j.proeng.2016.04.145.

[18] J. C. Morel, A. Mesbah, M. Oggero, P. Walker. Building houses with local materials: Means to drastically reduce the environmental impact of construction. Building and Environment 36(10):11191126, 2001. DOI:10.1016/S0360-1323(00)00054-8

[19] V. B. Reddy, P. P. Kumar. Structural Behavior of Story-High Cement-Stabilized Rammed-Earth Walls under Compression. Journal of Materials in Civil Engineering 23(3):240-247, 2011.

[20] J. E. Oti, J. M. Kinuthia. Stabilised unfired clay bricks for environmental and sustainable use. Applied Clay Science 58:52-59, 2012. DOI:10.1016/j.clay.2012.01.011.

[21] S. Serrano, L. Rincón, B. González, et al. Rammed earth walls in Mediterranean climate: Material characterization and thermal behaviour. International Journal of Low-Carbon Technologies 12(3):281-288, 2017. DOI:10.1093/ijlct/ctw022

[22] J. A. H. Oates. Lime and Limestone: Chemistry and Technology, Production and Uses. Wiley,, 1st edn., 1998. 
[23] S. Mindess. Concrete. Prentice-Hall,, 1st edn., 1981.

[24] M. Holub, C. Stone, M. Balintova, R. Grul. Intrinsic Hydrophobicity of Rammed Earth. IOP Conference Series: Materials Science and Engineering 96(1):012024, 2015. DOI:10.1088/1757-899X/96/1/012024

[25] E. Nemecz. Clay Minerals. Akadémiai Kiadó,, 1st edn., 1981.

[26] Q. B. Bui, J. C. Morel, B. V. Venkatarama Reddy, W. Ghayad. Durability of rammed earth walls exposed for 20 years to natural weathering. Building and Environment 44(5):912-919, 2009. DOI:10.1016/j.buildenv.2008.07.001
[27] H. Niroumand, J. A. Barceló Álvarez, M. Saaly. Investigation of earth building and earth architecture according to interest and involvement levels in various countries. Renewable and Sustainable Energy Reviews 57(Supplement C):1390-1397, 2016. DOI:10.1016/j.rser.2015.12.183

[28] A. Jing. A History of the Great Wall of China. World Scientific Publishing Company, 2015.

[29] Q.-B. Bui. Assessing the Rebound Hammer Test for Rammed Earth Material. Sustainability 9(10):1904, 2017. DOI:10.3390/su9101904 